\title{
PENGGUNAAN PENDEKATAN SAINTIFIK UNTUK MENINGKATKAN HASIL BELAJAR PENDIDIKAN AGAMA KATOLIK BAGI SISWA KELAS V SDI TARAWAJA TAHUN PELAJARAN 2018 / 2019
}

\author{
YUSTINA LEWA \\ GURU SDI TARAWAJA, KECAMATAN SOA \\ Email:Yustinalewa@gmail.com
}

\begin{abstract}
Abstrak
Tujuan penelitian ini adalah untuk mengetahui peningkatan hasil belajar melalui penggunaan pendekatan saintifik bagi siswa kelas V SDI Tarawaja Tahun Pelajaran 2018/2019. Jenis Penelitan penelitian adalah penelitian tindakan kelas (PTK). Desain penelitian yang digunakan adalah model Kemmis dan Mc Taggart yang pada hakikatnya terdiri dari 3 tahap yaitu, perencanaan, tindakan \& pengamatan, dan refleksi yang mana ke 3 tahap diatas merupakan satu siklus. Metode atau Teknik pengumpulan data yang digunakan dalam penelitian ini adalah menggunakan metode tes dengan bentuk tes pilihan ganda. Sedangkan analisis data menggunakan statistik deskriptif kuantitatif. Hasil penelitian pada siklus I setelah diterapkan dengan pendekatan saintifik telah menunjukan bahwa rata-rata skor hasil belajar yang dicapai oleh siswa sebesar $69,5 \%$ dan berada pada kategori cukup aktif. Sedangakan pada siklus II, rata-rata skor hasil belajar yang diperoleh peserta didik yaitu $80,5 \%$ dan berada pada kategori baik. Sedangkan peningkatan dari siklus I ke siklus II adalah $11 \%$, hal ini menunjukan bahwa penggunaan pendekatan saintifik dapat meningkatkan hasil belajar siswa dalam pelajaran pendidikan agama katolik di kelas V SDI Tarawaja. Peningkatan ini terjadi karena siswa telah memahami materi, pendekatan yang diterapkan membuat siswa aktif, kreatif dan mengasah pikiran siswa untuk mampu memecahkan tugas yang diberikan guru. Dengan demikian dapat disimpulkan bahwa penggunaan pendekatan saintifik dapat meningkatkan hasil belajar pendidikan agama katolik bagi siswa kelas V SDI Tarawaja tahun pelajaran 2018/2019.
\end{abstract}

Kata-kata kunci: Hasil Belajar, Pendekatan Saintifik, Pendidikan Agama Katolik 


\section{PENDAHULUAN}

Secara nomatif, pendekatan atau metode Saintifik dapat ditelusuri melalui sejarah pemikiran yang terangkum dalam Filsafat IImu, yang tercatat sejak jaman Yunani sampai jaman kontemporer dewasa ini. Secara formal, pendekatan Saintifik dapat ditelusuri pada dokumen Kurikulum 2013, sebagai pengusung metode pembelajaran berkerangka ilmiah di sekolah. Dokumen Kurikulum 2013 menerangkan bahwa pendekatan Saintifik adalah pendekatan ilmiah yang dapat digunakan untuk pengembangan sikap, keterampilan, dan pengetahuan peserta didik.

Peraturan Menteri Pendidikan dan Kebudayaan Republik Indonesia Nomor 81a Tahun 2013 Tentang Implementasi Kurikulum Pedoman Umum Pembelajaran, mengamanatkan Strategi pembelajaran yang melibatkan pendekatan Saintifik, sangat diperlukan untuk menunjang terwujudnya kompetensi yang terurai dalam Kurikulum 2013, serta cara bagaimana siswa mampu mencapainya untuk membentuk watak, membangun pengetahuan, sikap dan kebiasaankebiasaan untuk meningkatkan mutu kehidupan peserta didik. Dengan demikian kegiatan pembelajaran yang diharapkan mampu memberdayakan semua potensi peserta didik untuk menguasai kompetensi yang diharapkan. Pemberdayaan diarahkan untuk mendorong pencapaian kompetensi dan perilaku khusus supaya setiap individu mampu menjadi pembelajar sepanjang hayat dan mewujudkan masyarakat belajar.

Agar siswa mampu mengembangkan sikap dan pengalaman sesuai dengan potensinya, maka proses pembelajaran yang diharapkan adalah peran guru tidak lagi sebagai pentransfer ilmu, melainkan sebagai fasilitator atau membantu siswa agar siswa mampu menguasai berbagai kompetensi yang diharapkan. Dalam proses pembelajaran Pendidikan Agama Katolik memiliki peran yang amat penting dalam kehidupan umat manusia. Dalam Raja Lieve menjelaskan bahwa Pendidikan agama katolik adalah usaha yang dilakukan secara terencana dan berkesinambungan dalam rangka mengembangkan kemampuan peserta didik untuk memperteguh iman dan ketaqwaan terhadap Tuhan Yang Maha Esa sesuai dengan ajaran Gereja Katolik, dengan tetap memperhatikan penghormatan terhadap agama lain dalam hubungan kerukunan antarumat beragama dalam masyarakat untuk mewujudkan persatuan nasional. Agama memiliki peran yang sangat penting dalam kehidupan umat manusia. Agama menjadi pemandu dalam upaya mewujudkan suatu kehidupan yang bermakna, damai dan bermartabat. Menyadari bahwa peran agama 
amat penting bagi kehidupan umat manusia maka internalisasi agama dalam kehidupan setiap pribadi menjadi sebuah keniscayaan, yang ditempuh melalui pendidikan baik pendidikan di lingkungan keluarga, sekolah maupun masyarakat.

Berdasarkan hal di atas, kenyataan proses pembelajaran pendidikan Pendidikan Agama Katolik di kelas 5 SDI Tarawaja, siswa belum menunjukkan hasil belajar yang optimal yaitu masih dibawah KKM 75\% dalam mengembangkan dan meningkatkan kompetensi, kreativitas, kemandirian, kerjasama, solidaritas, kepemimpinan, empati, toleransi, dan kecakapan hidup sesuai yang diharapkan.

Untuk meningkatkan hasil belajar Pendidikan Agama Katolik tersebut, maka perlu diambil tindakan konknit sebagai langkah awal dalam menyelesaikan persoalan tersebut. Salah satu tindakan konkrit yang diambil adalah dengan menerapkan pendekatan saintifik dalam pembelajaran. Menunut Hosnan (2014) pendekatan saintifik adalah proses pembelajaran yang dirancang sedemikian rupa agar peserta didik secara aktif mengkonstruksi konsep, hukum atau prinsip melalui tahapan-tahapan mengamati (untuk mengindentifikasi atau menemukan masalah), menumuskan masalah, mengajukan atau menumuskan hipotesis, mengumpulkan data dengan berbagai teknik, menganalisis data, menarik kesimpulan dan mengkomunikasikan konsep, hukum atau prinsip yang ditemukan. Sedangkan menunut Daryanto (2014:51) pembelajaran dengan pendekatan saintifik adalah proses pembelajaran yang dirancang sedemikian rupa agar siswa secara aktif mengkonstruksi konsep, hukum atau prinsip melalui tahapan-tahapan mengamati, merumuskan masalah, mengajukan pertanyaan atau mengajukan hipotesis, mengumpulkan data dengan berbagai teknik, menganalisis data, menarik kesimpulan dan mengkomunikasikan konsep, hukum atau prinsip-prinsip yang ditemukan. Menunut Imas Kumiasih (201429) pendekatan saintifik adalah proses pembelajaran ya $\mathrm{ng}$ dirancang sedemikain rupa agar peserta didik secara aktif mengkonstruksikan konsep pembelajaran melalui tahapantahapan mengamati (untuk mengidentifikasi atau menemukan masalah) menumuskan masalah , mengajukan atau menumuskan hipotesis, mengumpulkan data dengan berbgai teknik, menganalisis data, menarik kesimpulan dan mengkomunikasikan konsep. Berdasarkan pengertian di atas maka diambil pendekatan saintifik untuk diterapkan dalam pelajaran, hal ini dilakukan karena pendekatan saintfik memiliki keunggulan salah satunya adalaah mengembangkan kreatiftas peserta didik dan menyediakan pengalaman belajar yang beragam. Maka dilakukan penelitian tindakan kelas dengan judul 
"Penggunaan Pendekatan Saintifik untuk Meningkatkan Hasil Belajar Pendidikan Agama Katolik Bagi Murid Kelas V SDI Tarawaja Tahun Pelajaran 2018/2019.

Berdasarkan latar belakang penelitian di atas maka rumusan masalah dalam penelitian ini adalah: “Apakah penggunaan pendekatan Saintifik dapat meningkatkan hasil belajar Pendidikan Agama Katolik bagi murid kelas $\mathrm{V}$ SDI Tarawaja Tahun Pelajaran 2018/2019? Sedangkan tujuan penelitian ini adalah untuk mengetahui peningkatan hasil belajar Pendidikan Agama Katolik dengan menggunakan pendekatan saintifik pada siswa kelas V SDI Tarawaja, Kecamatan Soa, Kabupaten Ngada Tahun Pelajaran 2018/2019.

\section{METODE PENELITIAN}

Jenis penelitan ini adalah penelitian tindakan kelas (PTK). Penelitian Tindakan Kelas adalah penelitan yang dilakukan oleh guru di dalam kelasnya sendiri melalui refleksi diri dengan tujuan untuk memperbaiki kinerjanya sebagai guru sehingga hasil belajar siswa menjadi meningkat khususnya peningkatan hasil belajar Pendidikan Agama Katolik (Aqib, 2009:3).
Tujuan utama Penelitian Tindakan Kelas adalah pengembangan kemampuan guru untuk mengulangi berbagai permasalahan pelajaran aktual yang dihadapi di kelas dan di sekolah melalui penelitian yang bersifat kolaboratif yang artinya antara peneliti dan mitra penelitian terjadi kerja sama yang saling melengkapi. Penelitian ini dilakukan dalam 4 tahap yakni perencanaan (planning), pelaksanaan (acting) pengamatan (observasi) dan refleksi (Reflecting).

Desain penelitian yang digunakan pada penelitian ini adalah model Kemmis dan Mc Taggart yang pada hakikatnya terdiri dari 3 tahap yaitu, perencanaan, tindakan \& pengamatan, dan refleksi yang mana ke 3 tahap diatas merupakan satu siklus (Tuniredja, 2010: 24). Penelitian ini dilaksanakan pada bulan juni sampai desember 2018. Penelitian ini rencanakan akan dilaksanakan di SDI Tarawaja, Kecamatan Soa Kabupaten Ngada. Subyek penelitian ini adalah siswa/i kelas V SDI Tarawaja berjumlah 36 orang siswa dengan rincian, 21 siswa laki-laki dan 15 siswa perempuan. Alasan peneliti memilih subyek tersebut karena ditemukan masalah hasil belajar siswa menurun. Obyek yang diteliti pada 
penelitian ini adalah hasil belajar Pendidikan Agama Katolik dengan menerapkan pendekatan Saintifik .

Metode atau Teknik pengumpulan data yang digunakan dalam penelitian ini adalah menggunakan teknik tes. Pada penelitian ini instrumen penelitian yang digunakan adalah instrumen Tes (soal evaluasi). Tes ini disusun berdasarkan tujuan pembelajaran yang akan dicapai. Tes ini diberikan setiap akhir pembelajaran. Bentuk tes yang diberikan adalah Pilihan ganda. Untuk mengetahui hasil belajar siswa, maka dilakukan penskoran dengan berpatokan pada sistem penilaian Kriteria Ketuntasan Minimal (KKM) mata pelajaran Pendidikan Agama Katolik adalah
$75 \%$, jadi jika tindakan dikatakan telah berhasil apabila hasil belajar siswa secara klasikal telah mencapai $80 \%$ atau berada pada kategori Baik (Tuntas).

\section{HASIL DAN PEMBAHASAN HASIL PENELITIAN}

Hasil belajar Pendidikan Agama Katolik diperoleh dengan menggunakan tes hasil belajar yang terdiri dari 20 soal yang diberikan dalam bentuk obyek (pilihan ganda). Dari tes yang dilaksanakan pada akhir siklus I ini diperoleh hasil belajar. Hasil belajar Pendidikan Agama Katolik siswa kelas $\mathrm{V}$ pada siklus I dapat dilihat pada tabel 4.4 berikut ini.

Tabel 1. Data Hasil Tes Siklus I

\begin{tabular}{|c|c|c|c|c|c|}
\hline No & Kode Siswa & \multirow{2}{*}{ KKM } & Nilai & \multicolumn{2}{|c|}{ Ketuntasan } \\
\cline { 5 - 6 } & & & & Tuntas & Belum Tuntas \\
\hline 1 & 01 & $\mathbf{7 5}$ & 65 & & $\sqrt{ }$ \\
\hline 2 & 02 & $\mathbf{7 5}$ & $\mathbf{7 5}$ & $\sqrt{ }$ & \\
\hline 3 & 03 & $\mathbf{7 5}$ & $\mathbf{7 5}$ & $\sqrt{ }$ & \\
\hline 4 & 04 & $\mathbf{7 5}$ & $\mathbf{7 0}$ & & $\sqrt{ }$ \\
\hline 5 & 05 & $\mathbf{7 5}$ & $\mathbf{7 5}$ & $\sqrt{ }$ & \\
\hline 6 & 06 & $\mathbf{7 5}$ & $\mathbf{7 5}$ & $\sqrt{ }$ & \\
\hline 7 & 07 & $\mathbf{7 5}$ & $\mathbf{7 0}$ & & $\sqrt{ }$ \\
\hline 8 & 08 & $\mathbf{7 5}$ & $\mathbf{7 5}$ & $\sqrt{ }$ & \\
\hline 9 & 09 & $\mathbf{7 5}$ & $\mathbf{6 5}$ & & $\sqrt{ }$ \\
\hline 10 & 010 & $\mathbf{7 5}$ & $\mathbf{6 5}$ & & $\sqrt{ }$ \\
\hline 11 & 11 & $\mathbf{7 5}$ & $\mathbf{7 5}$ & $\sqrt{ }$ & \\
\hline 12 & 12 & $\mathbf{7 5}$ & $\mathbf{6 5}$ & & $\sqrt{ }$ \\
\hline 13 & 13 & $\mathbf{7 5}$ & $\mathbf{7 5}$ & $\sqrt{ }$ & \\
\hline 14 & 14 & $\mathbf{7 5}$ & $\mathbf{7 5}$ & $\sqrt{ }$ & \\
\hline 15 & 15 & $\mathbf{7 5}$ & $\mathbf{6 5}$ & & $\sqrt{ }$ \\
\hline 16 & 16 & $\mathbf{7 5}$ & $\mathbf{7 5}$ & $\sqrt{ }$ & \\
\hline
\end{tabular}




\begin{tabular}{|c|c|c|c|c|c|}
\hline 17 & 17 & 75 & 65 & & $\sqrt{ }$ \\
\hline 18 & 18 & 75 & 60 & & $\sqrt{ }$ \\
\hline 19 & 19 & 75 & 60 & & $\sqrt{ }$ \\
\hline 20 & 20 & 75 & 75 & $\sqrt{ }$ & \\
\hline 21 & 21 & 75 & 65 & & $\sqrt{ }$ \\
\hline 22 & 22 & 75 & 75 & $\sqrt{ }$ & \\
\hline 23 & 23 & 75 & 60 & & $\sqrt{ }$ \\
\hline 24 & 24 & 75 & 75 & $\sqrt{ }$ & \\
\hline 25 & 25 & 75 & 65 & & $\sqrt{ }$ \\
\hline 26 & 26 & 75 & 65 & & $\sqrt{ }$ \\
\hline 27 & 27 & 75 & 60 & & $\sqrt{ }$ \\
\hline 28 & 28 & 75 & 75 & $\sqrt{ }$ & \\
\hline 29 & 29 & 75 & 65 & & $\sqrt{ }$ \\
\hline 30 & 30 & 75 & 60 & & $\sqrt{ }$ \\
\hline 31 & 31 & 75 & 75 & $\sqrt{ }$ & \\
\hline 32 & 32 & 75 & 75 & $\sqrt{ }$ & \\
\hline 33 & 33 & 75 & 65 & & $\sqrt{ }$ \\
\hline 34 & 34 & 75 & 75 & $\sqrt{ }$ & \\
\hline 35 & 35 & 75 & 75 & $\sqrt{ }$ & \\
\hline 36 & 36 & 75 & 75 & $\sqrt{ }$ & \\
\hline & Jumlah & & 2505 & & \\
\hline & Rata- rata & & 69,5 & 18 & 18 \\
\hline & Persentase & & & $50 \%$ & $50 \%$ \\
\hline & \multicolumn{2}{|c|}{ Ketuntasan Klasikal } & & \multicolumn{2}{|c|}{ Belum Tuntas } \\
\hline
\end{tabular}

Sumber : Data Hasil Penelitian Lapangan 2018

Dari tabel di atas menunjukkan bahwa secara klasikal hasil belajar pendidikan Agama Katolik belum tuntas yaitu sebesar $50 \%$ dan belum mencapai $\mathrm{KKM} 75 \%$. maka penelitian dilanjutkan ke siklus II.

Berdasarkan hasil tes belajar, ada beberapa hal yang perlu diperhatikan pada pertemuan siklus I, antara lain sebagai berikut. (1) Tujuan pembelajaran mutlak perlu disampaikan pada awal pembelajaran sehingga siswa mengetahui apa yang dipelajarinya. (2) Hubungan antara pembelajaran dengan pengetahuan awal harus lebih dipertajam sehingga ada keseimbangan materi.

Penggunaan bahasa yang sederhana dan mudah dimengerti sangat menentukan apakah proses pembelajaran mudah diserap atau tidak. (4) Pengelolaan kelas secara professional harus menjadi prinsip peneliti dalam keseluruhan proses pembelajaran, apakah itu terhadap 
rombongan belajar besar atau pun kecil.

Hasil belajar yang diperoleh pada siklus I sebesar 69,5\%. Pencapaian ketuntasan belajar yang ditentukan sekolah adalah 50\%. Oleh karena itu, peneliti bersepakat untuk melanjutkan penelitian ke siklus II dengan memperhatikan kekurangan-kekurangan (hasil refleksi) yang terjadi pada siklus I.
Hasil belajar Pendidikan Agama Katolik dinilai dengan menggunakan tes hasil belajar yang terdiri dari 20 soal yang diberikan dalam bentuk obyek (pilihan ganda) yang harus dikerjakan siswa secara individu. Dari tes yang dilaksanakan pada akhir siklus II ini diperoleh hasil belajar. Hasil belajar Pendidikan Agama Katolik siswa kelas $\mathrm{V}$ pada siklus II dapat dilihat pada tabel 4.12 berikut ini.

Tabel 2. Data Hasil Tes Siklus II

\begin{tabular}{|c|c|c|c|c|c|}
\hline No & Kode Siswa & \multirow{2}{*}{ KKM } & Nilai & \multicolumn{3}{|c|}{ Ketuntasan } \\
\cline { 4 - 6 } & & & & Tuntas & Belum Tuntas \\
\hline 1 & 01 & 75 & 75 & $\sqrt{ }$ & \\
\hline 2 & 02 & 75 & 90 & $\sqrt{ }$ & \\
\hline 3 & 03 & 75 & 100 & $\sqrt{ }$ & \\
\hline 4 & 04 & 75 & 70 & $\sqrt{ }$ & \\
\hline 5 & 05 & 75 & 75 & $\sqrt{ }$ & \\
\hline 6 & 06 & 75 & 100 & $\sqrt{ }$ & \\
\hline 7 & 07 & 75 & 80 & $\sqrt{ }$ & \\
\hline 8 & 08 & 75 & 75 & $\sqrt{ }$ & \\
\hline 9 & 09 & 75 & 85 & $\sqrt{ }$ & \\
\hline 10 & 010 & 75 & 60 & & \\
\hline 11 & 11 & 75 & 100 & $\sqrt{ }$ & \\
\hline 12 & 12 & 75 & 70 & $\sqrt{ }$ & \\
\hline 13 & 13 & 75 & 75 & $\sqrt{ }$ & \\
\hline 14 & 14 & 75 & 100 & $\sqrt{ }$ & \\
\hline 15 & 15 & 75 & 80 & $\sqrt{ }$ & \\
\hline 16 & 16 & 75 & 90 & $\sqrt{ }$ & \\
\hline 17 & 17 & 75 & 70 & $\sqrt{ }$ & \\
\hline 18 & 18 & 75 & 70 & $\sqrt{ }$ & \\
\hline 19 & 19 & 75 & 70 & $\sqrt{ }$ & \\
\hline 20 & 20 & 75 & 85 & $\sqrt{ }$ & \\
\hline 21 & 21 & 75 & 80 & $\sqrt{ }$ & \\
\hline 22 & 22 & 75 & 90 & $\sqrt{ }$ & \\
\hline
\end{tabular}




\begin{tabular}{|l|l|l|l|l|l|}
\hline 23 & 23 & 75 & 75 & $\sqrt{ }$ & \\
\hline 24 & 24 & 75 & 80 & $\sqrt{ }$ & \\
\hline 25 & 25 & 75 & 75 & $\sqrt{ }$ & \\
\hline 26 & 26 & 75 & 85 & $\sqrt{ }$ & \\
\hline 27 & 27 & 75 & 75 & $\sqrt{ }$ & \\
\hline 28 & 28 & 75 & 75 & $\sqrt{ }$ & \\
\hline 29 & 29 & 75 & 80 & $\sqrt{ }$ & \\
\hline 30 & 30 & 75 & 65 & & $\sqrt{ }$ \\
\hline 31 & 31 & 75 & 75 & $\sqrt{ }$ & \\
\hline 32 & 32 & 75 & 80 & $\sqrt{ }$ & \\
\hline 33 & 33 & 75 & 70 & $\sqrt{ }$ & \\
\hline 34 & 34 & 75 & 95 & $\sqrt{ }$ & \\
\hline 35 & 35 & 75 & 75 & $\sqrt{ }$ & \\
\hline 36 & 36 & 75 & 85 & $\sqrt{ }$ & \\
\hline & Jumlah & & 3060 & & \\
\hline & Rata- rata & & 80,5 & 34 & \\
\hline & Persentase & & & $94,7 \%$ & \multicolumn{2}{c|}{ Tuntas } \\
\hline & Ketuntasan Klasikal & & & & \\
\hline
\end{tabular}

\section{Sumber : Data Hasil Penelitian Lapangan 2018}

Dari tabel di atas menunjukkan bahwa secara klasikal hasil belajar pendidikan Agama Katolik tuntas yaitu sebesar $94,5 \%$ dan belum mencapai KKM 5,3\%. maka penelitian berhenti disiklus II ini.

Hasil belajar yang diperoleh pada siklus II mencapai $80,5 \%$ dengan ketuntasan belajar mencapai $94,7 \%$. Ada 2 orang siswa yang tidak tuntas belajar atau sebesar 5,3\%. Hal ini disebabkan karena siswa tersebut tidak hadir (absen) dan daya inteligensinya rendah sehingga ketuntasan belajarnya tidak mencapai KKM yang di tentukan. Pencapaian hasil belajar Pendidikan Agama Katolik pada siklus II telah melebihi pencapaian ketuntasan klasikal minimal (75\%). Dengan melihat hasil tersebut di atas dan berpedoman pada PAP maka dapat memberi kesimpulan bahwa hasil penelitian ini dikatakan tuntas dan penelitian berakhir pada siklus II.

\section{PEMBAHASAN}

Berdasarkan hasil penelitian pada siklus I setelah diterapkan dengan pendekatan saintifik telah menunjukan bahwa persentase 
hasil belajar yang dicapai siswa pada siklus I adalah sebesar $69,5 \%$ dan berada pada kategori cukup aktif. Hal ini disebabkan karena siswa belum terbiasa dengan pendekatan yang diterapkan oleh guru, banyak siswa kurang memperhatikan penjelasan guru, kurangnya pengelolaan kelas sehingga siswa menjadi ribut dan kurang konsentrasi.

Pada siklus II, rata-rata skor hasil belajar yang diperoleh peserta didik yaitu 80,5 dan berada pada kategori baik. Sedangkan peningkatan dari siklus I ke siklus II adalah $11 \%$, hal ini menunjukan bahwa penggunaan pendekatan saintifik dapat meningkatkan hasil belajar siswa dalam mengikuti pendidikan agama katolik di kelas V SDI Tarawaja. Peningkatan ini terjadi karena siswa telah memahami materi, pendekatan yang diterapkan membuat siswa aktif, kreatif dan mengasah pikiran siswa untuk mampu memecahkan tugas yang diberikan guru.

Hasil penelitian ini dapat dikatakan bahwa konsisten dengan hasil penelitian yang dilakukan oleh peneliti-peneliti terdahulu yang dikaji dalam penelitian yang relevan. Berdasarkan hasil penelitian pada siklus I dan siklus II diketahui bahwa pendekatan saintifik dapat meningkatan hasil belajar pendidikan agama katolik siswa kelas V SDI Tarawaja tahun pelajaran 2018/2019.

Tabel 3. Rekapitulasi Hasil Belajar Pendidikan Agama Katolik SDI Tarawaja

\begin{tabular}{|c|c|c|c|c|}
\hline No & Siklus & Siklus I & Siklus II & Peningkatan rata - rata (\%) \\
\hline 1 & Hasil Belajar & 69,5 & 80,5 & 11 \\
\hline
\end{tabular}

Dengan demikian dapat pendekatan saintifik dapat disimpulkan bahwa penggunaan meningkatkan hasil belajar 
pendidikan agama katolik pada siswa kelas V SDI Tarawaja Tahun Pelajaran 2018/2019.

\section{PENUTUP}

\section{SIMPULAN}

Berdasarkan hasil analisis data dapat disimpulkan bahwa penggunaan pendekatan saintifik dalam pembelajaran Pendidikan agama katolik dapat meningktatkan hasil belajar pendidikan agama katolik. Hal ini dibuktikan hasil penelitian pada siklus I setelah diterapkan dengan pendekatan saintifik telah menunjukan bahwa persentase hasil belajar yang dicapai siswa pada siklus I adalah sebesar $69,5 \%$ dan berada pada kategori cukup. Pada siklus II, ratarata skor hasil belajar yang diperoleh peserta didik yaitu 80,5 dan berada pada kategori baik. Nilai peningkatan dari siklus I ke siklus II adalah $11 \%$, hal ini menunjukan bahwa penggunaan pendekatan saintifik dapat meningkatkan hasil belajar siswa dalam mengikuti pendidikan agama katolik di kelas $\mathrm{V}$ SDI Tarawaja. Peningkatan ini terjadi karena siswa telah memahami materi, pendekatan yang diterapkan membuat siswa aktif, kreatif dan mengasah pikiran siswa untuk mampu memecahkan tugas yang diberikan guru.

Hasil penelitian ini dapat dikatakan bahwa konsisten dengan hasil penelitian yang dilakukan oleh peneliti-peneliti terdahulu yang dikaji dalam penelitian yang relevan. Berdasarkan hasil penelitian pada siklus I dan siklus II diketahui bahwa pendekatan saintifik dapat meningkatan hasil belajar pendidikan agama katolik siswa kelas V SDI Tarawaja tahun pelajaran 2018/ 2019.

\section{Saran}

Berdasarkan temuan-temuan dalam penelitian, pembahasan dan simpulan di atas maka beberapa saran yang diajukan antara lain sebagai berikut.

a) Bagi Peneliti 
Mendapatkan

pengalaman

melaksanakan proses pembelajaran dengan membantu siswa melakukan refleksi diri tentang sesuatu yang dimengerti dan yang belum dimengerti dalam rangka meningkatkan hasil belajar.

b) Bagi Siswa

Adanya peningkatan hasil belajar siswa sehingga siswa terdorong untuk melakukan perubahan proses belajar, sebagai wahana baru dalam

\section{DAFTAR PUSTAKA}

Aqib, 2009. Penelitian Tindakan Kelas untuk Guru. Bandung:Yrama. Widya.

Daryanto. 2014. Pendekatan Pembelajaran Saintifik Kurikulm 2013. Yogyakarta: Gava Media.

Hosnan.2014. Pendekatan Saintifik dan Kontekstual dalam Pembelajaran Abad 21. Bogor: Ghalia Indonesia.

Imas Kumiasih .2014. Implementasi Kurikulum 2013 Konsep \& Penerapan. Surabaya: Kata Pena. proses meningkatkan keaktifan, kreatifitas dan hasil belajar.

c) Bagi Guru

Sebagai masukan yang bermanfaat dalam merubah cara belajar siswa pada saat proses pembelajaran terutama untuk meningkatkan hasil belajar dan menentukan pendekatan pembelajaran dengan tujuan agar dapat meningkatkan keaktifan, kreatifitas dan hasil belajar siswa.

Permendikbud No. 81a Tahun 2013 tentang Implementasi Kurikulum Lampiran $\mathrm{N}$ tentang Pedoman Umum Pembelajaran.

Rajalieve.blogspot.com. diakses tanggal 21 Januari 2019

Tuniredja, 2010. Penelitian Tindakan Kelas Untuk Pengembangan Profesi Guru: Praktik, Praktis dan Mudah. Bandung: Alfabeta. 